Original Research Paper

\title{
Pelatihan Pembuatan Media Video Interaktif bertema "Tanaman Berkhasiat Obat"sebagai Ilmu Dasar Farmasi bagi Siswa SMP menuju Jenjang SMK Farmasi menggunakan Software Camtasia
}

\author{
Hanifah Karimatulhajj ${ }^{1}{ }^{*}$, Puji Handayani Putri², Ari Retno Purwanti ${ }^{3}$

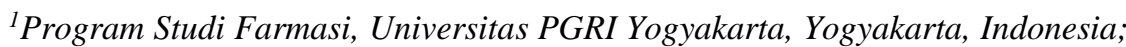 \\ ${ }^{2}$ Program Studi Teknik Informatika, Universitas PGRI Yogyakarta, Yogyakarta, Indonesia \\ ${ }^{3}$ Program Studi PPKN, Universitas PGRI Yogyakarta, Yogyakarta, Indonesia
}

https://doi.org/10.29303/jpmpi.v3i2.801

Sitasi: Karimatulhajj, H., Putri, P. H \& Purwanti, A. R. (2021). Konservasi Sumberdaya Alam Berwawasan Kearifan Lokal Melalui Sosialisasi Peningkatan Kesadaran Lingkungan Pada Masyarakat Desa Bagik Payung Timur, Lombok Timur. Jurnal Pengabdian Magister Pendidikan IPA, 4(3)

\author{
Article history \\ Received: 25 Agustus 2021 \\ Revised: 27 September 2021 \\ Accepted: 29 September 2021 \\ *Corresponding Author: \\ Hanifah Karimatulhajj, \\ Universitas PGRI Yogyakarta, \\ Yogyakarta, Indonesia; \\ Email: hanifah@upy.ac.id
}

\begin{abstract}
Tanaman Berkhasiat Obat merupakan salah satu Ilmu Dasar Farmasi yang diperlukan oleh siswa SMP yang ingin melanjutkan sekolah ke jenjang SMK Farmasi. Materi ini menjadi tema pelatihan pembuatan media video interaktif yang dibuat menggunakan software Camtasia. Pelatihan diberikan kepada guru untuk meningkatkan kemampuan membuat media pembelajaran mandiri. Selain itu diharapkan Materi Tanaman Berkhasiat Obat dapat diterapkan pada mata pelajaran IPA SMP oleh Guru.
\end{abstract}

Keywords: Ilmu Dasar Farmasi; Video intraktif; Camtasia

\section{Pendahuluan}

Pengetahuan merupakan hasil dari tahu, dan ini terjadi setelah orang melakukan penginderaan terhadap suatu objek tertentu. Penginderaan terjadi melalui panca indera manusia, yakni indera pengelihatan, pendengaran, penciuman, rasa, dan raba. Sebagian besar pengetahuan manusia diperoleh melalui mata dan telinga (Notoatmodjo, 2007).

Banyak faktor yang dapat mempengaruhi baik dan kurangnya pengetahuan seseorang. Faktorfaktor tersebut diantaranya yaitu pendidikan, semakin tinggi pendidikan seseorang maka makin mudah orang tersebut menerima informasi sedangkan pengalaman seseorang dapat memberikan pengetahuan dan keterampilan sehingga dapat memberi kemampuan mengambil keputusan.

Memperkenalkan tanaman obat harus dimulai sejak dini kepada anak-anak muda terutama usia remaja, karena pada usia ini keingintahuannya sudah semakin besar, mereka sudah mulai belajar menentukan pilihan. Materi Tanaman Berkhasiat Obat merupakan Ilmu Dasar Farmasi yang perlu diberikan kepada siswa SMP khususnya bagi yang ingin melanjutkan sekolah ke jenjang SMK Farmasi.

Kekayaan alam tumbuhan di Indonesia meliputi 30.000 spesies tumbuhan dari total 40.000 spesies tumbuhan di dunia, 940 spesies diantaranya merupakan tumbuhan berkhasiat obat (Masyhud, 2010). Tumbuhan obat merupakan seluruh spesies tumbuhan yang diketahui mempunyai khasiat obat dimana dapat menghilangkan rasa sakit, meningkatkan daya tahan tubuh, membunuh bibit penyakit dan memperbaiki organ yang rusak (Agromedia, Redaksi. 2003). Bagian tanaman obat yang sering digunakan berupa akar, kulit batang, kayu, daun, bunga atau bijinya (Adfa, 2005). Pengetahuan tentang tanaman berkhasiat obat berdasar pada pengalaman dan keterampilan yang secara turun temurun telah diwariskan dari satu 
generasi ke generasi berikutnya. Selain itu, arti penting tanaman obat tradisional bagi kehidupan manusia perlu mendapat perhatian serius, terutama dari anak-anak muda sebagai generasi penerus, di samping karena tanaman langka yang dimiliki Indonesia semakin bertambah jumlah statusnya menjadi terancam punah, juga karena kecilnya perhatian terhadap uji klinis tanaman, khususnya tanaman obat, seperti yang diungkapkan dalam majalah Trubus dengan tema Infokit Herbal Indonesia Berkasiat dikatakan bahwa tanaman ungulan nasional yang telah diuji klinis diantaranya yaitu salam, sambiloto, kunyit, jaher merah, jati belanda, temulawak, jambu biji, cabai jawa, dan mengkudu (Trubus, 2010). Bukti kecilnya perhatian terhadap tanaman obat, menurut Hariana, di Indonesia dikenal lebih dari 20.000 jenis tumbuhan obat. Namun, baru 1.000 jenis saja yang sudah didata, dan baru sekitar 300 jenis yang sudah dimanfaatkan untuk pengobatan tradisional (Hariana, 2009). Hal ini menunjukkan betapa kecilnya perhatian maupun penggunaan tanaman obat. Alam yang paling dekat dengan siswa adalah tumbuhan, obat tradisonal banyak berasal dari tumbuhan dan mudah ditemui siswa saat di sekolah maupun di rumah, tanaman yang berkhasiat obat di lingkungan sekolah juga bisa dimanfaatkan sebagai pertolongan pertama kalau ada siswa yang terluka dan sakit. Selain itu obat tradisional memiliki manfaat yang banyak, harganya murah, dan bisa dipetik kapan saja (Widodo, 2013).

Penyampaian materi dengan metode yang kurang menarik akan menyulitkan siswa dalam memahami materi. Minat dan pemahaman siswa dalam menyerap suatu ilmu dipengaruhi oleh jenis media pembelajaran yang digunakan. Audiovisual merupakan cara pembelajaran yang membantu meningkatkan minat dan pemahaman siswa. Menurut Nugent (2005) dalam Smaldino dkk (310 : 2008), video merupakan media yang cocok untuk berbagai macam pembelajaran, seperti kelas, kelompok kecil, bahkan satu siswa saat ini yang tumbuh berkembang dalam dekapan budaya teknologi. Maka dari itu, video dengan durasi yang hanya beberapa menit mampu memberikan keluwesan lebih bagi guru dan dapat mengarahkan pembelajaran secara langsung pada kebutuhan siswa.

Media pembelajaran interaktif berupa video audiovisual merupakan media ajar yang mendukung Guru untuk mencapai keberhasilan pengajaran. Video tersebut dapat dibuat dan diedit menggunakan software salah satunya yaitu Camtasia. Materi pelajaran yang terlihat sulit akan lebih mudah difahami oleh siswa jika dirancang menggunakan video audiovisual. Oleh karena itu pelatihan pembuatan video pembelajaran audiovisual menggunakan software Camtasia dilakukan dengan peserta Guru untuk meningkatkan kemampuan guru dalam membuat media ajar yang disukai dan mudah difahami oleh siswa. Dengan adanya alat bantu berupa video pembelajaran akan memberikan kemudahan pada guru kelas dalam mengemas materi pembelajaran yang memerlukan penjelasan lengkap. Sehingga siswa dapat mengkaji materi pembelajaran secara lengkap dan berulang-ulang di setiap waktu.

\section{Metode}

Pelatihan diberikan kepada 20 orang Guru SMP Mataram Kasihan Yogyakarta dengan 3 tahapan, yaitu Tahap (1) Penjelasan Materi Tanaman Berkhasiat Obat dan Camtasia. Materi diberikan dalam bentuk powerpoint untuk dipelajari oleh Guru. Selanjutnya Guru akan mempelajari materi Camtasia dengan penjelasan dan pendampingan. Tahap ini diberikan kepada Guru untuk memudahkan Guru dalam membuat video audiovisual menggunakan software Camtasia, selanjutnya tahap

(2) peserta diberikan kesempatan untuk praktik membuat video dengan pendampingan. Peserta memadukan antara media power point dengan rekaman suara yang dibuat sesuai dengan setiap slide power point. Di dalam video tersebut dapat ditampilkan penjelasan dan fisik guru Guru, kemudian tahap,

(3) peserta dipersilahkan untuk bertanya, mendapatkan penjelasan yang lebih dalam terkait Camtasia video, dan menyelesaikan video pembelajaran yang dibuat oleh masing-masing Guru.

Pengetahuan tentang tanaman berkhasiat untuk Siswa SMP disajikan dalam bentuk file ppt, dimana file ppt tersebut akan ada penjelasan lengkap dari Guru berupa audio/naskah. Sehingga materi tentang tanaman berkhasiat tersebut dapat disajikan secara lengkap dan mendetail. Materi ppt tanaman berkhasiat ini ditambah pula gambaran tentang materi Biologi yang berkaitan dengan Metabolit Sekunder, Tanaman Berkhasiat Obat, dan 
Obat Tradisional sebagai dasar dalam pengetahuan di sekolah lanjutan (SMK Farmasi). Materi tersebut
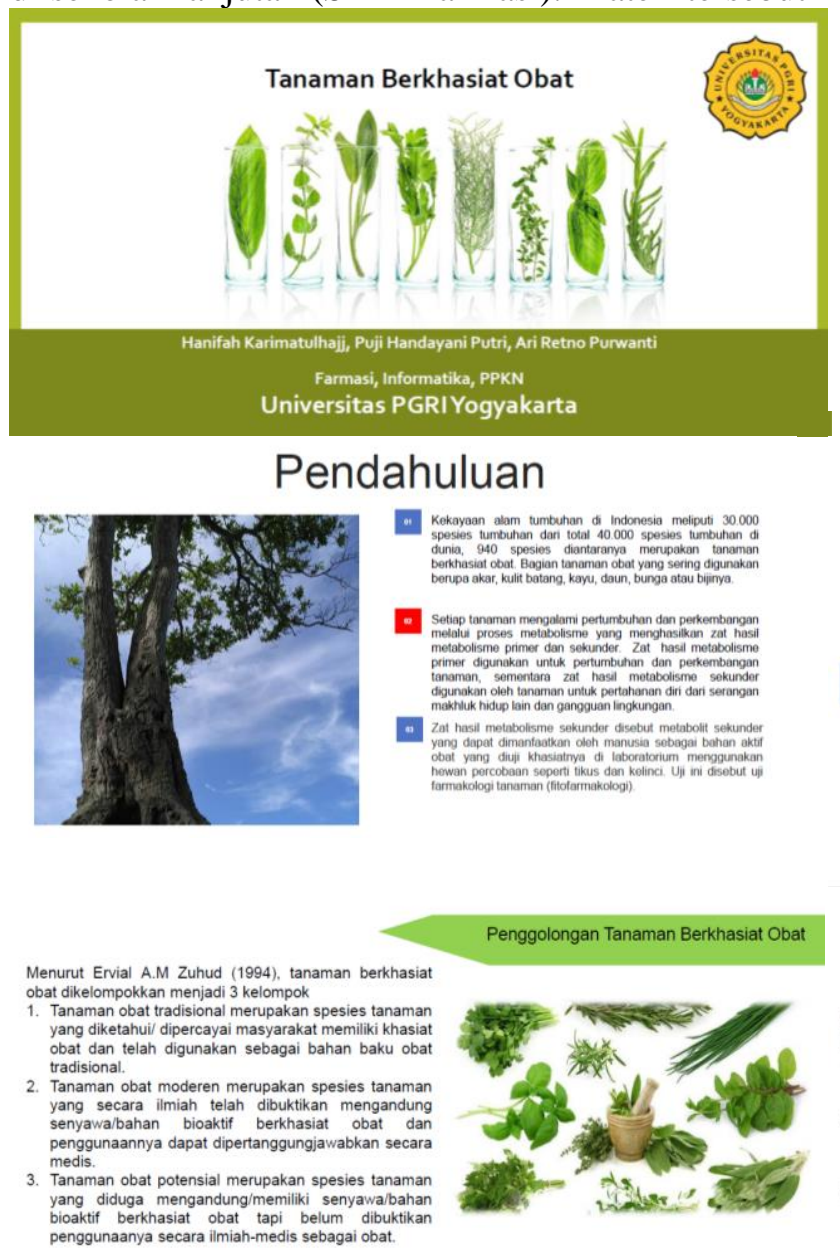

terdapat dalam Gambar 1.
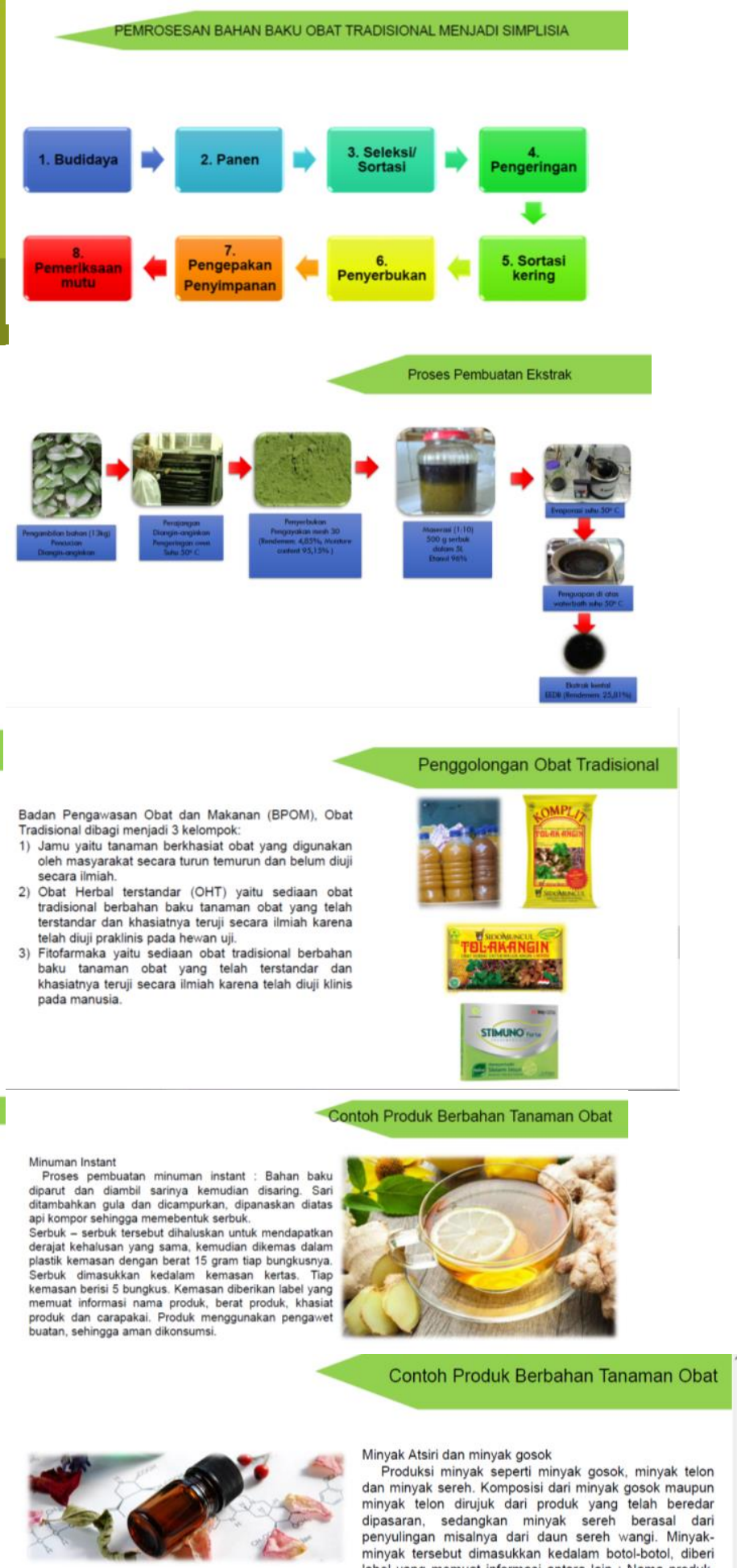

Minyak Atsiri dan minyak gosok

Produksi minyak seperti minyak gosok, minyak telon dan minyak sereh. Komposisi dari minyak gosok maupun
minyak telon dirujuk dari produk yang telah beredar dipasaran, sedangkan minyak sereh berasal dari penyulingan misalnya dari daun sereh wangi. Minyak. minyak tersebut dimasukkan kedalam botol-botol, diberi label yang memuat informasi antara lain : Nama produk. komposisi minyak (minyak gosok dan minyak telon). khasiat, cara pakai volume minyak dan tempat produksi.

\section{Gambar 1. Materi Tanaman Berkhasiat Obat}




\section{Hasil dan Pembahasan}

Pengabdian Masyarakat yang telah dilaksanakan yaitu Pelatihan Pembuatan Video Pembelajaran menggunakan Camtasia Studio kepada Guru dengan sampel Materi Tambahan Biologi terkait Tanaman Berkhasiat di SMP Mataram Kasihan. Peserta pelatihan merupakan Bapak Ibu Guru matapelajaran IPA, TIK, PKN sejumlah 20 peserta. Pendampingan dilaksanakan selama 3 kali pertemuan pada tanggal 25, 27, dan 29 Mei 2021 dengan total 32 jam. Pendampingan pertama diawali dengan penginstalan software camtasia studio, pembagian modul pelatihan, pengenalan software camtasia studio, mempersiapkan alat yang dibutuhkan berupa headphone dan smartphone.

Pendampingan kedua, mempersiapkan materi tentang tanaman berkhasiat dalam bentul slide power point. Guru mulai melakukan perekaman audio penjelasan materi tambahan biologi terkait tanaman berkhasiat. Bersamaan dengan hal tersebut, guru merekam video presentasi dan melakukan perekaman aktivitas layar komputer menggunakan software camtasia studio.

Pendampingan ketiga, tahap akhir antara lain tahap rendering video yaitu menggabungkan semua file audio video dan rekam layar komputer menjadi satu kesatuan sehingga menghasilkan video pembelajaran berformat avi. kemudian video .mp4 tersebut diunggah pada channel youtube untuk mendapatkan link akses video https://youtu.be/jbMaBdZiKlo. Link akses video tersebut yang diberikan kepada siswa untuk mempelajari materi tambahan biologi terkait tanaman berkhasiat.

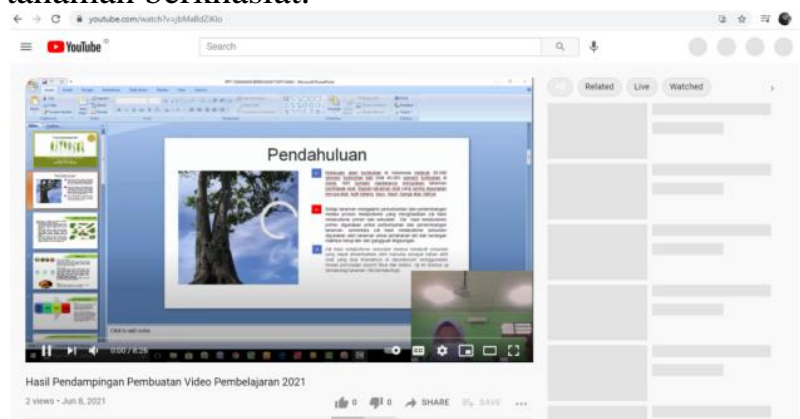

Gambar 2. Hasil Video pada Youtube Channel

Hasil yang diperoleh dari kegiatan pelatihan pada guru tersebut ialah guru dapat menciptakan solusi pembelajaran yang menarik minat siswa dalam belajar yaitu menerapkan materi pelajaran dalam sebuah video .mp4 dan menguploadnya pada channel youtube sehingga memudahkan siswa dalam mengakses video .mp4 tersebut. Manfaat lain yang didapatkan oleh siswa ialah memiliki pengetahuan dasar ketika siswa sekolah lanjutan kejuruan bidang Farmasi.

Pelatihan dihadiri oleh 20 peserta Guru SMP Mataram Kasihan Bantul dengan perbandingan wanita dan laki-laki yaitu 7 laki-laki dan 13 wanita. Peserta wanita memiliki kemampuan yang cepat dalam menyelesaikan pembuatan video menggunakan software Camtasia. Sementara itu jumlah peserta yang belum menyelesaikan program yaitu berjumlah 15 peserta. Di tahap 1 peserta mendapatkan penjelasan terkait materi powerpoint Tanaman Berkhasiat Obat.

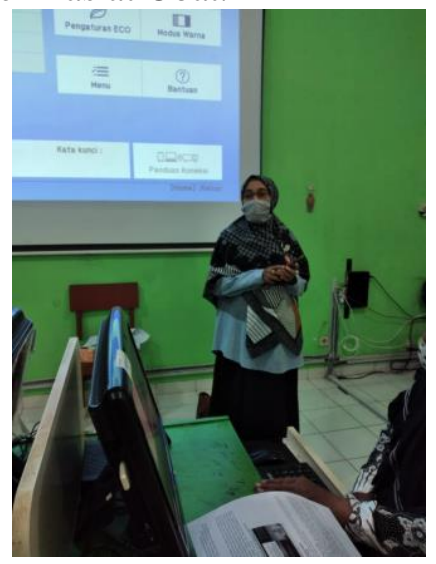

Gambar 3. Pemateri Tanaman Berkhasiat Obat

Di tahap 2 peserta praktik membuat video interaktif Tanaman Berkhasiat Obat dengan mengombinasikan antara powerpoint dengan peragaan dosen dengan suara.

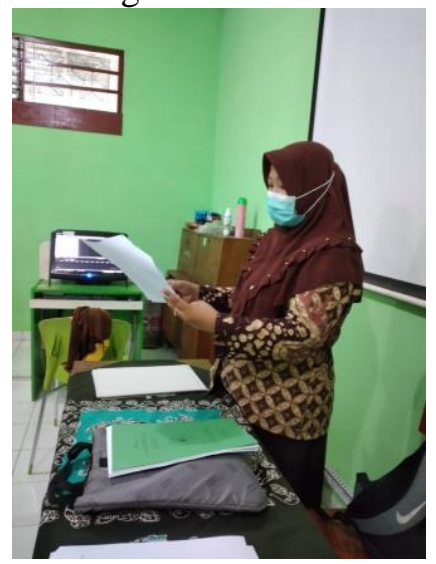

Gambar 4. Pemateri Camtasia Studio

Di tahap 3 hanya didapatkan persentase peserta yang kecil yang mampu membuat video hingga tahap akhir. Dari 20 peserta hanya ada 5 peserta yang mampu menyelesaikan pembuatan video hingga tahap akhir. 


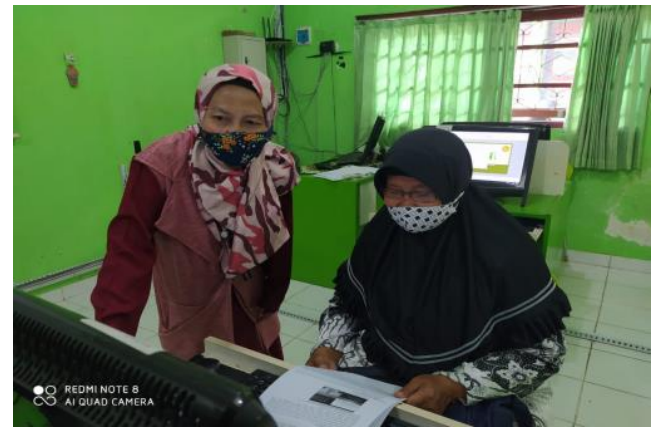

Gambar 5. Pendampingan Peserta

Keberhasilan pembuatan video pembelajaran oleh ke-5 guru tersebut dapat di bagikan ketrampilannya pada guru yang lainnya. Faktor keberhasilan penguasaan pembuatan video pembelajaran dipengaruhi oleh faktor usia guru. Guru usia muda dapat lebih cepat menguasai praktek pembuatan video pembelajaran dibandingkan guru usia lanjut.

\section{Kesimpulan}

Berdasarkan pelatihan yang telah dilakukan selama 3 hari pelatihan yaitu 25, 27, dan 29 Mei 2021, semua pelatihan berjalan dengan baik dan lancar walau dilaksanakan secara pelan-pelan dan berulang. Terdapat 5 peserta yang dapat menyelesaikan pembuatan video pembelajaran sampai tahap akhir. Keberhasilan pembuatan video pembelajaran tersebut dapat disampaikan lebih lanjut pada guru mapel yang lain. Sehingga kemampuan guru dalam membuat video pembelajaran dapat merata dan guru dapat menerapkan video pembelajaran pada masingmasing matapelajaran yang diampu sebagai alat bantu pembelajaran yang menarik siswa dalam belajar terlebih dalam kondisi pandemi saat ini.

\section{Saran}

Pelaksanaan pelatihan selanjutnya dapat mengembangkan pembuatan video pembelajaran yang lebih kompleks lagi menggunakan camtasia studio misalnya dengan menambahkan fitur animasi didalamnya sebagai alat bantu memvisualisasikan ilmu pengetahuan.

\section{Ucapan Terima Kasih}

Penulis mengucapkan terima kasih kepada Program Studi Farmasi Fakultas Sains dan Teknologi Universitas PGRI Yogyakarta yang telah mendukung kegiatan pengabdian, berkat dukungan tersebut penulis dapat menyelesaikan kegiatan ilmiah ini dengan baik, terimakasih pula pada LPPM Universitas PGRI Yogyakarta yang telah mendukung kegiatan Pengabdian Masyarakat ini. Mengucapkan terimakasih pula pada Mitra SMP Mataram Kasihan Yogyakarta yang sudah bekerjasama dalam kegiatan pengabdian ini.

\section{Daftar Pustaka}

Adfa, M. (2005). Study Senyawa Flavonoid dan Uji Brine Shrimp Beberapa Tumbuhan Obat Tradisional Suku Serawai di Provinsi Bengkulu. Jurnal Gradien 1(1): 43-50.

Agromedia, Redaksi. (2003). Ramuan Tradisional untuk Mengatasi Aneka Penyakit. Jakarta: PT Agro media

Hariana, A. H., (2013). 262 Tumbuhan Obat dan Khasiatnya. Jakarta : Penerbit Swadaya

Masyhud. (2010). Lokakarya Nasional Tanaman Obat Indonesia (TOI). Badan Litbang Kesehatan. Jakarta

M.B. Dixon, Claire Broadley, Dixon, Camtasia Studio 8 : Advanced Editing and Publishing Techniques. 2013.

Mulyani E.S, S. 2006. Anatomi Tumbuhan. Yogyakarta:Kanisius

Notoatmodjo, S. (2007). Promosi Kesehatan dan Ilmu Perilaku. Jakarta : Rineka Cipta.

Pessarakli, M. 2001.Handbook of Plant and Crop Physiology Second Edition Revised and Expanded. New York: Marcel Dekker, Inc.

Shah, B. And Seth, AK. 2010.The textbook of Pharmacognosy \& Phytochemistry. India: Elsevier

Tjitrosoepomo, Gembong. 1985. Morfologi Tumbuhan. Yogyakarta: UGM Press.

Trubus. (2010). Herbal Indonesia Berkhasiat: Bukti Ilmiah \& Cara Racik. Trubus Swadaya Volume 08; 355-356 Widodo. (2013). Psikologi Belajar. Jakarta : PT. Rineka Cipta. 